FTPV \#997355, VOL 0, ISS 0

\title{
Abd-el-Krim al-Khattabi: The Unknown Mentor of Che Guevara
}

\author{
MEVLIYAR ER
}

\section{QUERY SHEET}

This page lists questions we have about your paper. The numbers displayed at left can be found in the text of the paper for reference. In addition, please review your paper as a whole for correctness.

Q1: Au: Please confirm if all keywords are desired.

Q2: Au: Attributed to? connected to?

Q3: Au: Attributed? connected?

Q4: Au: Outfits? As in clothes?

Q5: Au: Publisher name available for note 15 ?

Q6: Au: City of publisher available for Dosal (note 43)?

Q7: Au: Publisher info available for note 64?

Q8: $\mathrm{Au}$ : If note 74 is a chapter in an edited book, please provide publisher info, page nos., and editor name(s).

Q9: Au: Publisher city available for note 75 ?

Q10: Au: Is note 79 a chapter in an edited book? If so, please provide editor(s) names.

Q11: Au: City available for Pioneer Publishers in note 79?

Q12: Au: Publisher city available for Scheina?

Q13: Au: City available for Bockman, note 89 ?

\section{TABLE OF CONTENTS LISTING}

The table of contents for the journal will list your paper exactly as it appears below:

Abd-el-Krim al-Khattabi: The Unknown Mentor of Che Guevara Mevliyar Er 


\title{
Abd-el-Krim al-Khattabi: The Unknown Mentor of Che Guevara
}

\author{
MEVLIYAR ER
}

The Muslim Women's Institute for Education, Cologne, Germany

\begin{abstract}
Abd-el-Krim Al-Khattabi's guerilla tactics are said to have influenced several renowned revolutionaries, such as Ho Chi Minh and Mao Zedong. There is evidence that Che Guevara equally employed at least some of the tactics and methods, which were devised by the Rifis. After all, Alberto Bayo, the much respected guerilla trainer of Che, had fought during his military career for a relatively long period of time against the Rifis. Castro, yet another role model for Che, mentions in his biography that he read about the battle of Annual, one of the most successful attacks against the Spanish initiated by Abd-el-Krim in 1921. There are also claims that Che had met Abd-el-Krim in 1959 in Cairo. Castro does not mention that he had discussed with Che anything about his readings on the Rif war, but he clearly states that Bayo used to teach in his camp guerilla methods that he had encountered during his assignments in Morocco. However, neither Bayo nor Che (or their biographers) mention that any of the tactics imparted during the trainings were from the time of Abd-elKrim's struggle. The only person praised by both men is the Nicaraguan rebel leader Augusto César Sandino. This article compares the tactical teachings of Bayo as well as the operational methods used by Che during his battles in Cuba with the methods applied by the Rifis under Abd-el-Krim's leadership and highlights a number of tactical similarities. It also finds that the guerilla tactics applied by Sandino have little in common with the methods described by Bayo.
\end{abstract}

Keywords Abd-el-Krim, Alberto Bayo, Augusto César Sandino, biographies of rebel leaders, Che Guevara, Cuban revolution, Fidel Castro, guerilla tactics, guerilla warfare, Morocco, Rif War

Initiating a successful insurrection, revolution, or revolt against an established system of official military forces certainly requires a high degree of tactical ingenuity. Large amounts of financial means invested in counterinsurgency measures, the time needed to repress any form of resistance, and the number of casualties among government forces only confirm this fact. The biographies of well-known rebel leaders - be it for lack of knowledge or even for reasons of unduly high esteem and glorification - do not elaborate much on the persons who may have been a source of inspiration for and/or knowledge acquisition of military tactics for such leaders. One example where this claim is evident is Che Guevara (1928-1967), who is considered to be one of the most successful anti-imperialist guerilla leaders to date. However, there are strong indications that the guerilla tactics of the Rifi rebel leader

Mevliyar Er is affiliated with The Muslim Women's Institute for Education (BfmF e.V), Cologne, Germany.

Address correspondence to Mevliyar Er, The Muslim Women's Institute for Education (BfmF e.V), Werkstattstr. 30b, 50733 Köln, Germany. E-mail: mevliyar@hotmail.com 
Abd-El-Krim Al-Khattabi (1882-1963), for instance, had attracted the attention of several renowned revolutionaries including Che Guevara. Many aspects of Che's life have been topics for academic research, but no in-depth study exists to date that explores these claims. A possible explanation for the omission among researchers in addressing this topic - apart from the reluctance to associate a man who stands as a symbol for numerous noble virtues worldwide with anyone else - could be mere Orientalism. It may also be because of ideological differences between the two icons: Krim's ideology was based upon Islamic ideals whereas Che's were based on Marxism-Leninism. The neglect may equally be to do with the lack of attention given to Abd-el-Krim by revolutionary hagiography and literature. Not without reason do Kunz and Müller refer to the Rif resistance as a war which made history but failed to enter the books of history. ${ }^{1}$ The aim of this article is to cover this particular gap in the literature and to explore the connection between Che and Abd-el-Krim by specifically investigating the question of whether Che was influenced by any of the guerilla tactics applied by Abd-el-Krim and his soldiers. The article finds that every possible avenue of knowledge transfer was present between the two rebel leaders: film productions, print publications, interaction with participants such as war veterans, and face-to-face meetings. Similarities in the conduct of operations examined here demonstrate additionally that the claims that Che Guevara was influenced by Abd-el-Krim al-Khattabi are not entirely unfounded. Apart from broadening our knowledge on biographical facts about Che and highlighting the phenomenon of transmission of military knowledge across anti-colonial guerrilla movements, the article suggests that neither religious affiliation nor cultural background stand in the way of inter-organizational learning among insurgent groups, if the actors are united by their perception of injustice.

This article additionally contributes to the existing knowledge on anti-colonial history and rebel leadership by tapping historical sources in German. Pioneering works on Abd-el-Krim's struggle such as by Rupert Furneaux (1967), David S. Woolman (1968), David M. Hart (1976), Richard Pennel (1986), and Shannon E. Fleming (1991) largely ignore publications as well as primary sources from Germany. However, Germans played a significant role during the Rif war. Several German legionnaires of the French foreign legion, who had fought in Morocco, wrote testimonies on their return back home, which are preserved in the Political Archives of the Federal Foreign Office in Berlin. Apart from these there are several other untapped German historical sources. More recent scholarly publications in Germany, in particular the extensive doctoral thesis of Dirk Sasse (2006), utilize some of these rare documents and publications.

The article proceeds in three sections. The first provides a brief overview about Abd-el-Krim's biography and the strategic innovations that were characteristic for the Rifi method of combat; the second part is about the mechanisms of knowledge transmission from Abd-el-Krim to Che Guevara; and the final part assesses the similarities in the way the two rebel leaders conducted their military operations.

\section{Mohammed Abd-El-krim Al-Khattabi’s Biography and His Strategic Innovations}

Mohammed Abd-El-Krim Al-Khattabi became an icon throughout the world for initiating extensively organized resistance initially against the Spanish and then the French imperial powers during the years 1921 to 1926. Until then, neither of the 
two powers had ever encountered a firmly united opponent that was politically as well as militarily astonishingly well-organized. Abd-El-Krim's life and his military achievements can be briefly summarized as follows: Abd-el-Krim's family, briefly referred to as Khattabis in this article, was from the most numerous and powerful tribe, namely Beni Urriaguel (or Ait Waryigel), in the Rif, a region of Morocco. ${ }^{2}$ The Khattabis ruled for more than a thousand years, enjoyed a good reputation, and hence were influential throughout the region. ${ }^{3}$ Krim's father was a judge (qadi), a profession practiced through generations in the family not least due to its long tradition of specializing in the field of Islamic studies. ${ }^{4}$ When the Spanish imperial powers expanded into the Rif, it was under the leadership of Abd-el-Krim's father that they experienced their first clashes. ${ }^{5}$ Abd-el-Krim's mother was the daughter of a Muslim judge. Abd-el-Krim and his brother, Si M'hammed (1893-1967) who would later play a significant role in Abd-el-Krim's successes-pursued Islamic studies from a very young age. ${ }^{6}$ Being from a family with higher social status, Abd-el-Krim and his brother also had the privilege of studying at degree level: While Abd-el-Krim advanced his studies with regard to Islam at the University in Fes, Morocco, Si M'hammed became a qualified mining engineer in Spain. ${ }^{7}$

Abd-el-Krim grew up in a relatively war-torn environment, the causes of which ranged from claims to the throne in Morocco to blood feuds between families or tribes. For this reason, Abd-el-Krim mentions in his memoirs that he was used to war and to the smell of gun powder since early childhood. ${ }^{8}$ At the University of Karauien in Fes, Abd-el-Krim (then aged 22) learned, in addition to his studies of the Qur'an, musketry and horsemanship. ${ }^{9}$ During the process of his post-graduate studies of Islamic and Spanish law to become an Islamic judge - which he accomplished with an excellent qualification in 1912 at the age of 30 - he worked for the Department of Native Affairs, wrote articles in Arabic for El-Telegrama del Rif, was an interpreter in the Central Office of Indigenous Troops and Affairs, and translated for diverse mining companies. ${ }^{10}$ In 1913, as an Islamic judge for the Spanish Central Office, Abd-el-Krim's work had mainly to do with the organization of the Protectorate, such as the legal aspects of rights and title deeds to the iron deposits of Beni Tuzin, which bordered on his own tribal area.

Given their position, both father and son were initially loyal to the Spanish. In this regard, Fleming notes that "Abd-el-Krim and his father also helped organize a Spanish faction in their home kabyle [here referring to the task of Abd-el-Krim as a judge for the Central Office]. For this act, the elder Abd-el-Krim was awarded the Cross of Military Merit and an annual pension of fifty pesetas, while the younger was named qadi al qudat, or chief Islamic judge of the Melillan region." 11 Abd-elKrim justifies this loyalty with the belief that the Rif would never attain economic progress without foreign involvement and the hope that the Spanish would help to modernize the Rif. ${ }^{12}$ Among several other economic deficiencies, a major hindrance to development was in fact poor infrastructure in the region. Due to its geographical location and surrounding mountain ranges, the region was relatively isolated from the rest of the country. Hence, the Rif was relatively poor compared to the other regions, a phenomenon dubbed the "Mezzogiorno effect" by economists of our time. Terhorst, an eyewitness of those times, describes the Rif region as follows: "2,000 meter high, gloomy, coarse and steep mountain chain extends along the North African Mediterranean coast between Melilla and Ceuta. The veil of the unexplored stretches mysteriously over this stage-like mountain world. The Rif is still a mystery, has still something dark, unknown to the European. Two Englishmen tried to move deeper into 
the mountains; but no one ever heard anything from them. Apparently a Frenchmen has managed to cross the Rif in 1600." 13 Another reason for the loyalty was the idea of using the Spanish as a shield against the French colonial powers, which became particularly important when the Sultan had signed the Act of the conference of Algeciras on April 7, 1906, which had entitled the French to establish a protectorate over Morocco.

However, when the Spanish gradually began to advance into Beni Urriaguel, Abd-el-Krim and his family began to experience unfair practices inflicted on the locals directly. The French, who had gained control over the heartland of Morocco, were equally not in an amicable relationship with the local population. Zaeper reports: "On the next day, our troop's task was to collect taxes from a rebellious Arab tribe. This took place under conditions of difficult clashes requiring very high losses, as the tax evaders resisted desperately. Some of the German comrades made here their last breath."14 This incident clarifies the extent of injustice the Rifis must have felt, especially when taxes were hardly paid to the Sultan. Further unfair practices followed suit: The Spanish authorities began to cut the incomes of the leaders of the tribe, including the father of Abd-el-Krim, and instead were paying bribes to tribesmen whom they expected to help in their efforts to expand into the Central Rif more readily. Abd-elKrim started taking action by criticizing these corrupt practices as well as colonialism as a driver for economic progress first through his job as journalist. ${ }^{15}$

In 1915, when questioned by his employer, Abd-el-Krim gave a written declaration stating his opposition against all oppressors of Islam, his support for the Turks, and his plans to establish an independent Rif in the unoccupied territories. ${ }^{16}$ Consequently, he was dismissed from all his posts, imprisoned for eleven months, and was even used as hostage against his father. He was eventually released after his father had agreed to continue cooperating with the Spanish. The uneasy relationship finally came to an end in 1918 when the Spanish continued to subjugate more tribes. Dissent among the population was exacerbated by a bad harvest, which was further complicating the already prevalent poor economic conditions. ${ }^{17}$ Organised resistance started under the leadership of Krim's father. At the beginning of 1919, monetary fines (haqq) charged to criminals, which had been abolished by the Spanish, were reintroduced and extended to apply to collaborators as well, inevitably leading to more unity among the tribes. The Rifis felt the reward of unity when they foiled a major attack led by General Silvestre from the sea. Nevertheless, he still managed to enter by using a different route later on. Confronted by the imminent threat of Spanish invasion, Abd-el-Krim's father started a campaign but died unexpectedly in August 1919. There were speculations that his father's death was due to a poison administered by the Spanish. ${ }^{18}$ With his death, the harakah (troop) disintegrated so that the Spanish could proceed with their plans for invasion without any resistance up until the beginning of 1921. Together with his brother, Abd-el-Krim continued the campaign started by their father to form an inter-tribal alliance against Spain. Being a charismatic leader and an impressive speaker, he recorded more success than his father managed to achieve: In April 1921, he was elected by fifty Shaikhs as their military leader. ${ }^{19}$ Political as well as religious decisions equally fell within the scope of Abd-el-Krim's duty. Propaganda against the Spanish, penalties imposed upon those who refused to perform military service, and decriminalization of the killers of collaborators are only a few examples of the extensive measures Abd-el-Krim had managed to implement effectively. Soon after his election, Abd-el-Krim had managed to form a sizeable army. ${ }^{20}$ Two victories won on a single day proved that the oath was well-deserved: In a surprise attack on 
June 2, 1921 launched on Dhar Ubarran, the majority of Spanish troops were killed. Similarly, General Silvestre's troops ended with a defeat in Sidi Idris. ${ }^{21}$ These victories encouraged more and more men to join Abd-el-Krim's troops. However, none of these successes was as triumphant as the one attained in Annual on July 17, which lasted for five days. There are significant discrepancies concerning the number of troops on both sides: The estimated numbers for the Spanish troops range between 25,000 and $30,000^{22}$ and for the Rifis 3,000. ${ }^{23}$ The Spanish death toll-including General Silvestre - according to one source is estimated to have been at least $10,000{ }^{24}$ Other historians set the death toll higher, at up to between 13,000-19,000 fatalities including captives. $^{25}$ This defeat was perceived as an "absolute miracle" - as Krim's brother called it-by the Rifis: Abd-el-Krim ordered that Quranic verses be recited and prayers of thanks performed for the attained and the upcoming victory over the Spanish. ${ }^{26}$ The colonial forces, in turn, dubbed the clash as "the disaster of Annual." The reconquest of the areas lost in the past continued and the Rif Republic was proclaimed on February 1, 1923. In July 1924, the Spanish experienced another crushing defeat in Chaouen where they lost about 10,000 soldiers. ${ }^{27}$ As in 1921, this was also a surprise attack where the Spanish had to give up one post after another, facilitating even more influence to Abd-el-Krim.

In the beginning of 1924, the Rifis began to observe problems initiated now by the French colonial powers: The Ouergha valley, one of the most fertile regions of the Rif, was an important source of supply for agricultural produce to Rifians and it began to be of interest to the French, too. Under the excuse of rearrangement of plot boundaries, the French began to build blockhouses (blocaos) and military posts around the valley. Food was already short due to contaminated soil: Between 1924 and 1926, the Spanish had resorted to using the acutely poisonous chemical warfare agent S-Lost (Yperit) on a large scale by the aero-chemical method for the first time in history. ${ }^{28}$ Not only were the guerilla fighters their target but also villages and water resources. The Ouergha valley was largely spared from the contamination.

Under pressure from his people to take action, Abd-el-Krim decided to attack the French. With this decision, as he later admitted, he made the greatest strategic mistake of his military career: He had not foreseen that the two competing imperial powers would eventually unite their manpower and resources against him. ${ }^{29}$ Initially the French, as the Spanish had earlier, were recording significant losses. Out of desperation and the fear of losing even Fes, the French General Lyautey saw no other solution than a joint operation with the Spanish to defeat the Rifis. Now the Spanish with 200,000 and the French with 160,000 men supported with the latest war technology were confronting the Rifi troops, consisting of about 60,000 to 80,000 men. ${ }^{30}$ The number of dead and missing French soldiers between April 1925 and May 1926 was 2,162. ${ }^{31}$ The territories lost were gradually re-conquered and on May 26, 1926 Abd-el-Krim was forced to surrender to the French forces. Together with his family, he was exiled to the French island La Réunion-located in the east of Madagascar. However, in 1947 on his way to France he managed to escape and lived henceforth in Cairo until his death in $1963 .^{32}$

It is an undisputed fact that the military techniques and tactics applied by the Rifians during the clashes caused great surprise, but also admiration, not only among the opponent soldiers but also among high-rank officers. In the context of the El Mers campaign on June 24, 1923 in which the French forces had 200 casualties, Windrow, for instance, remarks: "Prince Aage [a French captain of royal descent] saw them coming in from his left front; he took professional pleasure in the 
skill with which they alternated between mounted movements and skirmishing on foot with carbines." ${ }^{33}$ Furthermore, in order to get thorough understandings of the diaries of the operations, remnants of the battles including ruins of buildings such as forts, trenches or hills never ceased to be subject to scrutiny by military experts since the end of the Rif war. ${ }^{34}$ Scholarly studies on Abd-el-Krim and the Rif war frequently characterize Abd-el-Krim as co-inventor of modern guerilla tactics.

Some of the tactics and methods that are mentioned in the literature with great amazement are as follows: the use of trenches (e.g., on May 3, 1925 General Colombat was unable to break through the Berber trenches encircling Bibane, despite six hours of fighting ${ }^{35}$ ); caves dug in the slopes ${ }^{36}$; extensive use of granite ramparts, rocks, boulder-strewn summits in the hills as concealment/cover from which to target the enemy; the use of smokeless-powder rifles that made it impossible to locate its user; hiding cannons in caves and using these exclusively at night, which made their discovery impossible. ${ }^{37}$

Worldwide research on the Rif war is unanimous that the war tactics of the Rifis were emulated during other rebellions such as the Druze war of Syria against France (1925-1927), the Algerian war of independence against France (1954-1962) and the Vietnam War against the United States (1946-1954). ${ }^{38}$ Twentieth-century anticolonial revolutionary leaders - such as the Vietnamese leaders Hô Chi Minh (18901969) and Võ Nguyên Giáp (1911-2013), the Yugoslav leader Tito (1892-1980), and Che Guevera - are specifically mentioned as being influenced by the military tactics of Abd-el-Krim. ${ }^{39}$ In this regard, Seymour says, "a great Muslim anti-imperialist fighter (whose successful tactics would inspire Ho Chi Minh and Che Guevara)."40 It has also been alleged that Abd-el-Krim had become an established key figure in the field of politico-military advice for revolutionary leaders during his time in exile in Egypt. Sneevliet, for instance, mentions that, "Revolutionary leaders of the world always paid him a visit when they came to Egypt.",41

However, Abd-El-Krim's influence on Che Guevara is either referred to in passing or briefly mentioned in footnotes in a couple of authentic sources such as in the biography of Fidel Castro (1926-) and Sebastian Balfour's Deadly Embrace. ${ }^{42}$ During a personal communication, Balfour said in this regard: "Che Guevara would have learnt about Abd el Krim from the Spanish Republican veteran of the Moroccan colonial campaign, Alberto Bayo [born in 1892 in Cuba - died in 1967 in Cuba], who trained him and other Castro fighters in Mexico before the Granma expedition in 1956. Bayo had been impressed by Abd el Krim's guerrilla tactics." 43 There are also claims that Che had met Abd-el-Krim twice in 1959 in the Moroccan embassy in Cairo to deepen his expertise in guerilla tactics. ${ }^{44}$ Little information is available as to what specifically has been copied by other revolutionaries. The writers on the Rif war unanimously agree that the contentious spirit of the Rifians-not least triggered by the idea of jihad and martyrdom — was one of the main determinants of their success. Another factor that gave the Rifians a competitive edge was their ability to cope with the demands of the guerrilla life. The Rifi warriors were used to the difficulties associated with living in the Atlas Mountains, had a good knowledge of the topology of the Rif, and were extraordinarily acclimatized to both the excessive heat as well as the cold rainy seasons. ${ }^{45}$ For this reason, Abd-el-Krim himself once made the supercilious statement that one Rifian would beat any ten Frenchmen. ${ }^{46}$

During the battles and ambush attacks, the Rifis are also known to have used mountains, cliffs, and bushes in an astonishing way, for their own advantage. Che, having realized the advantages of the Moroccan terrain, is said to have greeted 
Abd-el-Krim with the words: "By flying over Rif by air, I looked out from the Window. The region is an ideal zone for guerilla." 47 Apart from these factors, few other guerilla tactics are still mentioned in the literature as having been typical for the Rifians. These fall into three different categories of defense techniques, namely siege war, attack on armored cars, and bayonet-versus-knife fighting.

The siege war techniques used by the Rifian soldiers are the most enthusiastically and vividly described methods that can be found in the literature on the Rif war. Woolman - one of the leading researchers on the Rif war-refers to one such tactic as follows: "Mhamed Abd el Krim's strategy and tactics were simple but effective. The Rifians were to surround each small enemy outpost and attempt to take it by sneak attack. If this failed, they were to wait for the garrison to run short of water or bullets, then kill the besieged men as they made a break for freedom. These tactics worked to perfection in eastern Spanish Morocco during the Anual rout." 48 Abd-el-Krim himself sees as the reason for the success in Dhar Ubarran and Sidi Idris on June 2, 1921 the division of the Spanish troops into blockhouses which were encircled by the Rifian armies in a surprise attack. ${ }^{49}$

Another innovative siege warfare technique applied by the Rifis was the so-called double ring of trenches dug around posts or camps, which they used to beat back resupply attempts or to prevent access by rescue parties. ${ }^{50}$ Only a few incidents are known where foreign legionnaires managed to get through the camps. ${ }^{51}$ In the rare case where legionnaires managed to break through the first one, they would be held back by the second ring.

Kunz and Müller mention briefly another Rifi military tactic, which-as claimed by them - was successfully practiced later on by other infantrymen from across the world. ${ }^{52}$ By referring to Woolman, the authors describe the method of attacking armored cars: "While some men controlled the tank's crew through rifle shots into the vision slits, the others used to creep up onto the vehicle to throw grenades (produced by local craftsmen) into the hatch." ${ }^{, 5}$ Woolman's version is as follows: "The Spanish opened fire as soon as the enemy appeared, but although the guns brought down some of the Rifian attackers, others dropped to the ground and waited until the cars lumbered closer. Jumping up, the Rifians surrounded each car, fired their rifles through the ports, and set fire to the gasoline tanks, thus completely destroying the armored cars."54 Windrow states that the Rifis would lay flat to avoid being seen by the crew. ${ }^{55}$ The first of such attacks took place on March 18, 1922 against the Spanish tank company equipped with twelve French Renault FT-17s. In a joint operation with the Legion infantry, their task was to drive the tribe Beni Said from the towns of Tugunz and Ambar. ${ }^{56}$ The Legion suffered 86 casualties during this counter-attack by the rebels.

A further tactical approach that was identified as being unique to the Rifis relates to the use of bayonet-versus-knife fighting. Windrow describes this method as follows: "it was whichever side showed the most aggression that had the essential advantage. On the receiving end of a determined bayonet-charge the Berbers, like any other fighting men, would themselves 'float', and this tactic - if exactly timed, and carried out with real resolve - was successfully employed often enough for veteran officers to regard it as a panacea against any threat within 100 yards."57

\section{Mechanisms of Knowledge Transmission From Khattabi to Che}

The claim that Che had learned Rifi guerilla tactics through Bayo or that he admired Abd-el-Krim is not mentioned by any of Che's biographers. The evidence that Che 
had met Abd-el-Krim in Egypt is also only anecdotal. However, the following arguments may allay any doubts: Firstly, it is an undisputed fact that Che travelled extensively around the world to gain allies, during which he met numerous leaders. In 1959, he did indeed visit Egypt and met Gamal Abdel Nasser. Given his political intentions, Che's life was always at risk. Hence, not all visits he was making occurred in the public eye. To date it is not known how many leaders Che met. The claim that he had visited a man like Abd-el-Krim during his stay in Egypt away from the public eye does thus sound quite plausible.

Secondly, there is a possibility that Che might have read Abd-el-Krim's biography. The Chinese Communist Leader Mao Zedong, for example, is known to have been knowledgeable about Abd-el-Krim's leadership. He told a Palestinian delegation of Fatah in 1971 the following: "You have come to me to hear me speaking about a people's liberations war, but in your own recent history you have Abd-el-Krim. He is of one the most important inspiration sources, of which I have learned what the people's liberations war exactly is." ${ }^{, 5}$ Castro, a contemporary of Che, equally talks with amazement about his readings on the battle of Annual of July 1921, as already mentioned. Interest in publications of this genre should apply all the more to Che, since one of his main character traits was being an enthusiastic and eclectic reader. In particular, biographies were of significant importance for Che: Apart from a couple of other genres he also recommends keeping biography books of past heroes as one of the few carefully selected essentials in the knapsack of a guerrilla fighter in the hope that it will be useful in raising the cultural level of the soldiers. ${ }^{59}$ Abd-el-Krim's biography was published very soon after his capture. A French journalist had a rare chance to conduct an interview with him as soon as he was captured and published it as biography in 1927. Given the worldwide reputation of Abd-el-Krim, the book was circulated widely. Its German translation came out in the very same year. Unconfirmed sources state, for instance, that Mao Zedong held a copy of it. ${ }^{60}$

Publications about Abd-el-Krim's struggle in the print media did not end with his capture. In fact, books, be they scholarly or in the form of novels about Abd-elKrim or the Rif war, never ceased to be published throughout the world. Scholarly work, as the ones used in this article, were only published after Che's death, but during Che's lifetime publications, mostly in the form of semi-fiction, continued to remain under the impact of Abd-el-Krim's achievements during the twenties. Che might have read one or the other of these publications, as novels as well as poetry remained his lifelong passion. Some examples of publications are worth mentioning here: Stookie Allen, an American cartoonist, described in a graphic novel entitled "Men of Daring: Abd-el-Krim, Napoleon of Morocco (True Story in Pictures)" Abd-el-Krim's achievements in Argosy Weekly (July 13, 1935), which dedicated stories to heroes and adventurers. ${ }^{61}$ The Spanish private soldier Ramón J. Sender, who did his military service in Morocco during the 1920s until 1924, wrote the Spanish novel Imán in 1934 (in England published under the title Earmarked for Hell and in the U.S. under Pro Patria) in which he describes Abd-el-Krim's defense and the destruction of innumerable forward Spanish garrisons under his command. At the same time, the life of the German deserter Josef Klems (1893-1938), who had fled from the French Legion to the Rif, became a source of inspiration for novelists. ${ }^{62}$ Klems was the only European advisor in the General Staff of Abd-el-Krim. ${ }^{63} \mathrm{He}$ played an important role as chief of artillery and was the only European who had assumed the leadership of a unit consisting of European deserters. The first of such novels or stories was written by P. C. Wren in 1934, the author of Beau Geste, with 
the title "Port o'Missing Men" which, as he, referring to Klems, claims is: "the true story of the life of a very remarkable man who was, according to one's point of view, a brilliantly clever and most courageous Soldier of Fortune, or a shameful and disgusting traitor." ${ }^{64}$ Another novel called Il Sergente Klems was written by Paolo Zappa in 1935 about his life. ${ }^{65}$ The most recent novel-with an impressive amount of factual information about the Rif war, Abd-el-Krim, and Klems - known to the author is El León Dormido (2005) by Marian Izaguirre.

There were other productions, which cannot be possibly assumed to have escaped Che's attention. The Rif rebellion in itself, facilitating plot elements such as a desert setting for romance films or as one of the world's most dangerous battlefields in the heart of the burning Sahara to which the main characters are exposed, never ceased to be used in a range of films made in France, Spain as well as in Hollywood. Starting from 1921 until 1998, and ignoring Spanish as well as French productions, more than twenty Hollywood movies can be identified. These are in chronological order as follows: The Sheik (1921), The Son of the Sheik (1926), Beau Geste (1926, 1939, 1966 and $\left.1977^{66}\right)$, The Desert Song (1929, 1932, 1943, 1953 and 1955) ${ }^{67}$, Morocco (1930), Renegades (1930), Drums of the Desert (1940), Road to Morocco (1942), Outpost In Morocco (1949), Ten Tall Men (1951), Saadia (1954), Sergeant Klems (1971), The Wind and the Lion (1975), March or Die (1977), and Legionnaire (1998).

Among these, The Desert Song was most popular. Romberg, "one of America's most beloved musical personalities during the second quarter of the twentieth century,", composed The Desert Song, one of the most internationally successful operettas in $1926{ }^{68}$ The Desert Song was fully adapted into film first in 1929 and then remade four more times. Its hero, "The Red Shadow," is said to have been inspired by Abd-el-Krim: "the mysterious Red Shadow, [is] an amalgamation of Rudolf Valentino, Lawrence of Arabia, and Abd-El-K[r]im, who helps the oppressed Moroccans (the Riffs) rise against their French colonial rulers." 69 Romberg's masked hero with a red cape who defends the Rifis against tyrannical Westerners using psychological mockery to confuse his opponents in turn was probably at least some of the inspiration also for Superman, one of America's most popular cartoon figures.

The continual media coverage on the Rif war is certainly associated with the impact of the amazement with which the world had followed the relative success of the Rifis against the technologically far better equipped imperial powers. It should therefore come as no surprise that a man like Abd-el-Krim, whose failure and capture was covered in newspapers under praiseworthy and eulogistic headings such as "Like Prometheus Chained to a Rock," had become a contact point for revolutionaries, which cannot be assumed to have been missed by Che. ${ }^{70}$

Still, there is another, perhaps more profound link between Abd-el-Krim and Che. It is known for certain that two persons closely associated with Che had great admiration for the Rifi warriors. One was Che's close comrade Fidel Castro. In his own autobiography, Castro says: "Later, in the twenties, Franco took part in a colonial war, in Morocco, in which the army had massive casualties. There was one battle, at Annual, in which Spain lost over 3,000 men. I've read the whole history of that war." 71 The second individual with even deeper connection with the Rifis was Che's guerilla trainer Alberto Bayo. Bayo had joined the Spanish army in 1916 and had become a pilot in the Air Force. His first assignments in Morocco are recorded to have started in $1919 .^{72}$ However, in 1923 , he was dismissed from duty as a consequence of his involvement in a bloody ending duel using sabres with another captain, namely Eduardo González Gallarza, who later become Minister for Air Force. 
Eventually, Bayo joined the elite corps Legion Española (the Spanish Foreign Legion), which was specifically founded to combat the rebels in Morocco. It was also during one of his missions in the Rif in 1925 (some sources state the date as being September 1924), when he was seriously wounded and even lost one eye. ${ }^{73}$ After the end of a one-year recovery period in Madrid, he resumed his fight against the Rifi rebels up until the end of the Rif war in 1927. There are also claims that he was one of the first pilots who had launched chemical agents from the air, possibly also into the Rif. ${ }^{74}$

Well-known for his achievements during the Rif war and the subsequent Spanish Civil War (1936-1939), he was approached by Castro in 1956 for the purpose of training his soldiers in Mexico for the Granma expedition against the Batista Rigime. ${ }^{75}$ The Castro brothers as well as Che Guevara took part in the training sessions. Che eventually became Bayo's model student. ${ }^{76}$ With regard to Che's relationship to Bayo, Dosal notes, "Guevara referred to Bayo as his master [E1 maestro], the only one he ever recognized.",77 Generally, most of the successes of the rebels against the Batista forces are adhered to Bayo's tactical teachings.

With regard to the source of Bayo's expertise on guerilla tactics, Abel and Fisch comment that through North African guerillas Bayo had discovered methods of fighting that occupied him for the rest of his life, and as a theoretician of these, he had attained popularity all over the world. ${ }^{78}$ The extent of Bayo's admiration for the tactics of the Rifis is put by Hansen as follows: "Castro succeeded in persuading Colonel Alberto Bayo to give a select group of cadres theoretical and practical training in guerrilla warfare. Bayo was well-known in Latin America as an expert in this field, having served in the Spanish forces that fought Abd El Krim in Morocco. The colonel became an admirer of the Moroccan guerrilla fighters and made a study of their tactics, which he sought, unsuccessfully, to place at the disposal of the Republican government of Spain in the civil war against Franco." 79 Bayo was convinced about the efficacy of these guerilla methods to such an extent that he refused to believe even the news, which announced the death of Che. To appease Hilde, for instance, he had said, "I can tell you this: he's the most intelligent, the cleverest - the one who most profited from my instruction. I am sure nothing has happened to him." 80

In 1955 Bayo published in Mexico his 150 Preguntas a un Guerrillero (150 Questions for a Guerilla) on how to be an insurgent and run an insurgency. Consisting of only 96 pages, the booklet describes tactics and techniques by addressing 150 questions. The booklet was translated into English in 1963, and given its success, it was re-printed several times. To date, it counts as one of the classics of the military literature on small wars.

The methods described in 150 Questions for a Guerilla are basics for our time. However, given the success of the book at the time, there is no doubt that they were relevant at the time it was written. Given the common nature of the methods, it is difficult to say whether the tactics described are a reflection of his time in the Rif. Nevertheless, two methods described by him raise suspicion that at least a few methods were learnt from the Rifis. For instance, in question 26 Bayo asks, "How should a police headquarters be attacked?" His response is as follows: "If the headquarters is built in the center of a lot one hundred yards wide by fifty in length, there will be fifty yards between the building and the fence surrounding it. First, we have to take the adjacent buildings with our fire force the garrison to take cover, waiting for reinforcements and outside help. Once in possession of a neighboring building and setting our riflemen around the headquarters so that no one can escape, we will begin our plan 
of attack as follows: In the building we have taken, we will dig a tunnel toward the center of the headquarters. Once we have the first shaft and the tunnel begun, we put two men with pick axes shoulder to shoulder digging a six-foot-high tunnel. Each one digs out a cubic yard of earth. They then withdraw while the dirt is quickly removed by others with shovels and baskets. When one side of the tunnel is clear of loose dirt, the shovel and basket men withdraw and the pick men begin again. All the workers thus have a break and can perform their tasks with greater efficiency. The tunnel bores away underground, just wide enough to allow two to work without interference. All work as fast as possible; the supervisor relieves the men when they seem to be slowing down.

It is next to impossible for reinforcements to reach the garrison by day so it will probably surrender. If it does not do so soon, it should be blown up-first with the object of taking it over; secondly, as a lesson for other police headquarters to surrender quickly. To hasten the job, not only one tunnel will be dug, but many leading under the headquarters. We do not know what kind of earth we will encounter in any one tunnel, nor whether the first mining attempt will be successful. A second or third bombing may be needed.

If on igniting the charge we discover that the blast is not underneath the building, our soldiers, ready and waiting, should be sent into the tunnel to reach the garrison from the crater or at least to occupy the crater. It has to be somewhere near the building and as such serve as a good place to attack the building from.... If, after the first explosion the garrison still does not surrender, we keep up work intensively on the other tunnels as well as in the first one. After an unsuccessful first attempt we should be able to correct the angle for the next try. Up to the time of the second bomb, the first crater can be used to pin down the occupants of the building from close by."

Tunnels were indeed dug extensively during the Rif war. Among these it is possible to find tunnels that were used as described by Bayo. One of the tunnels dug in Wad Aqermus in 1921 to undermine a Spanish fort may serve here as an example to show resemblances. ${ }^{81}$ Furneaux, yet another prominent researcher on the Rif war, writes the following upon his visit to the ruins in 1965: " 'That is the mouth of the tunnel we dug,' he [referring to a Rifi war veteran] told me. Peering inside I saw that the tunnel extended beneath the fort above. Abish [a Rifi who helped to dig it] led me to the hilltop; it was still encircled by an earthen parapet. In the centre of the fort was a large hole. 'That is where our gunpowder exploded'." 82

A further strong similarity relates to Bayo's description of the organizational structure of the guerilla army. In question 42 Bayo asks the following question: "What is the complement of a guerrilla company?" To which he gives the following response: "The tactical unit designated as the company contains one hundred men including the commander, a captain. A company has four lieutenants, each commanding a section. Including their lieutenants in command, the first three sections each contain twenty-five men, except for the last. The captain is the twenty-fifth member of the fourth company. Each section has two sergeants who in turn command a platoon apiece of eleven men. Each platoon has two corporals who command squads of five men each. In the squads a second corporal assists the corporals." Bayo further explains (under question 46) as to why the number of troops may vary at times: "Because this organization has nothing to do with combat operational necessities. A captain can command a hundred men, but does not have to use all of them together. On certain occasions, for example, in the siege of an army or police garrison defended by a small detachment, it is a good idea to use the whole guerrilla company for the assault. The captain who operates in certain sectors assigned to him by the Guerrilla Staff has his platoons of twelve 
men trebled to be perfect guerrillas; he will sometimes utilize groups of twenty-five men commanded by lieutenants." This organizational structure of the army has strong similarities to the structure set up by Abd-el-Krim. His army was divided into units consisting of 300 to 500 men, which in turn were divided into subgroups of 250, 100, 50,25 , and twelve men, each being led by supervising officers. ${ }^{83}$

\section{Similarities in the Conduct of Operations}

A few statements made by Castro regarding the teachings of Bayo with reference to the Rif war may help here to identify specific similarities in the conduct of operations between the two insurgencies. In his autobiography Castro comments that, "Bayo taught us how to set up a guerilla to break a defence the way Moroccans of Abd-el-krim faced with the Spanish." Castro further says: "Bayo never went beyond teaching what a guerrilla fighter should do to break through a perimeter when he's surrounded, on the basis of his experience of the times Abd el-Krim's Moroccans, in the war in the Rif, broke through the Spanish lines that encircled them." 84 Bayo himself addresses this method with his question 37.

Varied methods were used by the Rifis to break through enemy lines. In June 1921, for instance, the Spanish noticed that their tactics were changing and that they were beginning to adopt staggered retreats when abandoning a position. ${ }^{85} \mathrm{~A}$ thorough analysis of the description of the clashes show, however, that infiltration into enemy lines was indeed frequently used by the Rifis. Preventing relief columns from joining one another was yet another tactic of the Rifis. ${ }^{86}$ At the end of July 1924, to mention one example, the Oued Lau outpost line near Tetuan was isolated by Krim's forces and any relief attempt was fiercely attacked. 87 "It took 8th Company no less than three hours to get within 50 yards of the base of the rocks by alternate fire and rushes, but they were then pinned down, and two messengers sent back to appeal for artillery support were both shot as they ran." 88 The Battle of Las Mercedes which started on July 29, 1958 may serve here as an example of how Che, in turn, put a very similar tactic into practice. During this battle, this particular tactic turned out to be extremely vital when Guevara helped out Castro's guerilla columns, which were encircled by the government forces. Harris describes the scene based on the more detailed description by Bockman: "Guevara had the ability to see in his mind's eye the whole battlefield in any given encounter. He quickly figured out the army's plan and saw that Castro's columns could be saved from disaster only if the army reinforcements [a force of some 1,500 troops] heading toward the area were prevented from reaching the scene. As a result, Guevara ordered his men to ambush these troops and keep them from reaching the scene of the battle. His men succeeded in blocking the advance of the army reinforcements.... This action allowed Castro's columns to slip out of the trap set for them by the army. Years later, Major Larry Bockman of the U.S. Marine Corps Command and Staff College analyzed Guevara's tactics during this battle, and he concluded they were brilliant (Bockman 1984)."89

There is yet another tactic which is said to have been taught to Che by his mentor General Bayo that, equally, could be traced back to the Rifis. It relates to ambush, which is the main technique used in guerilla warfare. According to Harris, Che made an innovation to the ambush technique: "It requires that the enemy be on the move, ideally marching in file through a ravine, canyon, or pass, where the forces can be caught in a devastating crossfire. However, Che made an original contribution to this age-old tactic. In his writings, Che mentions the psychological damage inflicted 
on the enemy if the guerrillas always concentrate their fire on the advance elements of the army units they ambush. The enemy's soldiers realize they can expect almost certain death if they are in the advance positions of a column. This tactic, Che claimed, creates panic among the soldiers and may even lead them to mutiny if they are ordered to take the lead positions in a column marching through a suspected guerilla area." 90 Referring to the ambush of a large army unit consisting of about 180 men on August 29, 1957 by applying the technique of targeting the head of the approaching column, thereby inducing panic and retreat of the following units, Che wrote: "We continued this practice until it became an established system, so efficient that the soldiers stopped coming to the Sierra Maestra and even refused to be part of the advance guard."91 Similarly referring to the ambush at El Hombrito in August 1957, Dosal writes, "By aiming at the point man of the approaching company, the guerrillas had immobilized the entire army column. 'Little by little this tactic was being crystallized,' Che realized, 'and it finally became so systematic that the enemy literally stopped entering the Sierra Maestra, and there were scandals involving soldiers who refused to march in the forward spot'."92 Furthermore, referring to Che's ambushes (mentioning also the attacks at El Hombrito), Dosal mentions that Che "excelled at organizing and executing ambushes" and that he "learned the tactic from Alberto Bayo and perfected it in the Sierra Maestra. Even soldiers trained in counterinsurgency warfare had difficulty avoiding or fighting their way out of Che's ambushes." 93

Like in Che's ambushes, the tactic of targeting the vanguard was also one of the prime tactics of the Rifis. Windrow writes: "The Berbers did not give junior leaders the luxury of much time to think, and the man with the coloured képi and Sam Browne belt was a priority target." 94 Referring to the clashes during July 1925 Windrow writes: "The bereaved II/1st Foreign, south of Ouezzane, had been led by Captain Derain, doubling up in command of the battalion and his own 5th Company due to the heavy officer casualties." 95 Two reasons were decisive for these casualties. Firstly, the lack of "quick-thinking" officers or sergeants to cope with the Rifi warriors' advantages in close combat. ${ }^{96}$ Secondly, the foreign officers were not trained how to successfully defend themselves in guerilla war. ${ }^{97}$ These deficiencies become particularly evident with the following description in the context of clashes on the hills: "The moment of first occupying a summit was among the most dangerous, since the Berbers often counter-attacked immediately before the soldiers could organize a perimeter or set up machine guns.... As the first platoons reached a crest... tribesmen who had dropped a little way down the reverse slope might fire into their faces and launch an uphill rush at extraordinary speed." 98 At another point Windrow writes, "A few tribesmen noted for their ambush skills had been watching and remembering every detail for several days; the best shots with the best rifles occupied a height from which they could see far along the back-trail or even the fort gates, while those with old muskets hid themselves among the rocks and trees a few yards from the track. However antique their weapons, the first blast at point-blank range could always drop one or two légionnaires in their tracks."99

The diaries of former legionnaires analysed for the purpose of this article are full of descriptions of fear of going outside an outpost or fort, let alone being sent to the front line. Frequently, the front line was used as a punitive measure for those who broke the rules or committed offences in the army. Given the great danger looming outside outposts and forts, foreign legionnaires would only go out if it was an absolute necessity, such as in case of water shortage after the area was checked and guarded by Spahis, as described by Windrow: "If there were any Spahis with the main garrison they rode out first and occupied high points, but in all cases the machine guns 
in the watchtowers were cocked, riflemen manned the walls, and look-outs scanned the surrounding terrain with binoculars while the water parties led the mules to the river or well. Such corvées were preceded by an advance guard which went beyond the watering point to picket any overlooking crest." ${ }^{100}$ However: "The routes and timetables of both corvées and supply parties inevitably became predictable, and by the tenth time an NCO [non-commissioned officer] had carried out this duty without incident it was equally inevitable that he tended to relax his vigilance... This was the moment at which the Berbers would strike."101

Just like in the case of El Hombrito, routs triggered by fear as described by Che, were frequently observed in the Rif, too. Windrow gives a description: "On 3 September, near Souk de Ait Bazza, a series of fierce attacks on a Moroccan Skirmisher battalion 'produit un léger flottement'; this elegantly phrased panic ('a light floating...') was quelled by charges that cost two companies of I/2nd REI another 33 men killed." 102 Referring to the incident of Annual, Windrow notes: "The withdrawal on 22 June [1921] soon degenerated into a rout, and many men were ambushed and cut down. [General] Silvestre and his staff all died; the body of the native affairs officer Colonel Morales was handed back later." 103 During the resistance, significant number of indigenous legionnaires both from the Spanish and French protectorate armies had changed sides. In July 1921, for instance, nearly 5,000 were recorded to have deserted. ${ }^{104}$ The number of European deserters between 1921 and 1926 was estimated to have been at least 150 and the majority of these were Germans. ${ }^{105}$

Concerning the persistency with which the Rifis defended their posts using these tactics, as Che and his soldiers did in Sierra Maestra, Woolman says: "The forces at Melilla now numbered 36,000; led by Generals Sanjurjo and Calvalcanti, the Spanish slowly pushed their way to Nador, which they retook on August 13. Under intermittent attack from snipers, the Spanish struggled slowly onward; it took them almost two months to advance the few miles between Nador and Zeluan." 106

Apart from the two tactics, more precisely the method of breaking through a perimeter and organizing and executing ambushes, no other mention is made on Bayo's teachings in Che's biographies. However, it is highly unlikely that the teachings of a mentor, who had won such a deep respect with Che, were limited to these two methods only. Moreover, methods of breaking through encirclement are not limited to just preventing enforcement from reaching the battle scene. Similarly, the ambush technique entails more than just systematically attacking the vanguard. These assumptions gain even more significance when considering the fact that Che was instructed not only by Bayo but also by Castro, who had some knowledge about the Rif war. In light of the foregoing, there is reason to consider that there may have been more tactical similarities. The remainder of this section is an attempt to find any resemblance between Che's conduct of operations and the tactics that are claimed to have been Rifi innovations, i.e., the siege war methods, which were peculiar to Rifis and their method of attacking armored cars as mentioned above.

It is known that Che has repeatedly attacked outposts, remote naval barracks, bunkhouses, and even forts using similar methods like the Rifis. ${ }^{107}$ Army garrisons are referred to by some Che biographers as forts, as these serve the same purpose and are set within a compound with a large gate. ${ }^{108}$ Just as the Rifis, Che's forces would cut water sources to force besieged troops to surrender and also use extensive night attacks. ${ }^{109}$ As Harris puts it, they "would surround barracks or forts and then force them to surrender after cutting off their supplies and threatening to set fire to, or in some cases actually setting fire to, the buildings government forces occupied."110 
The battle of La Plata on January 17, 1957 and the battle of El Uvero on May 28,1957 were the start of a series of this type of attack. ${ }^{111}$ In both cases army compounds at the coast of the Caribbean Sea were the target of a surprise attack. In the case of El Uvero, a compound with several bunkhouses was surrounded at dawn by nine squads led by eight men, one of whom was Che. After almost three hours the garrison was forced to surrender. ${ }^{112}$ Yet another similar attack took place on July 31, 1957 in Bueycito: Che and his men encircled a barrack occupied by twelve men and wounded six and captured another six. The last of this type of attack took place in December 1958 when Che's column had launched surprise attacks on the garrisons of the Batista army and Rural Guard unit in the Las Villas Province. It is further known that Che had proposed to Kabile, one of the Congolose leaders, to target a poorly defended enemy outpost around the town Albertville. ${ }^{113}$

Scenes that were similar to the Rifi attacks on armored cars can equally be found during the Cuban revolution. During their last major attack on June 28, 1958 in Sierra Maestra, the lead battalion advancing into the mountain was ambushed by Che's troops. Armored cars were called to aid the situation but they were diverted by the rebels from the road to the roadsides, which were infested with mines. Having lost their protection, soldiers became an easy target for the snipers and the Batista army recorded 86 casualties while Che had only three. ${ }^{114}$ On December 27, 1958 Che successfully employed a similar method to an armored train with extensive amounts of war equipment in the city of Santa Clara. The soldiers were forced to surrender after Molotov cocktails were thrown into it. ${ }^{115}$

In addition to these, further tactical similarities can be observed between the two insurgencies. In 1963, Che summarizes the primary tactic of guerilla warfare: "Strike and run, wait, watch carefully, and then again strike and run." ${ }^{116} \mathrm{He}$ advises to repeat this over and over until the enemy is demoralized and takes a static and defensive posture. Windrow describes the battle of the highly organized French company III/3rd REI on May 6, 1922 with the Rifis where the latter seems to have taken the very same approach as proposed by Che: "Any halt other than to deliver a rapid fusillade encouraged the Berbers to concentrate their own fire, pinning the platoon down and creating a static target towards which the tribesmen were instinctively drawn."117 During this clash, the French had 99 casualties (40\% of their strength which included 17 killed, 64 wounded, and 18 missing). Rifis managed to apply this tactic even at a larger scale. During the winter of 1923-1924, for instance, more than a quarter of the foreign army was tied down in static positions without any plans to regain the initiative. ${ }^{118}$ Woolman cites the description of a Spanish legionnaire on how the Rifis used to defend themselves: "Abd el Krim's characteristic fighting tactics are to withdraw or retreat while the enemy advances, but at the first halt of the latter, to start sniping, at which the Moroccans are experts. And it is very difficult to shoot them down as they never collect in large groups, but in isolated bevies which are continually on the move; whereas the French and Spanish troops, moving in concentrated masses, are easy targets."119

Despite all these resemblances in the conduct of operations, there are claims that Bayo's most famous work, 150 Questions for a Guerilla, was inspired by the Nicaraguan rebel leader Augusto César Sandino (1895-1934), who had led a relatively successful resistance against the American military occupation of Nicaragua between 1927 to $1932 .{ }^{120}$ This claim is most likely due to the following note in Bayo's work: "Always remember that Sandino fought against the Americans for seven years without once being cornered in spite of his pursuers' many thousands of perfectly trained men 
with motorized units and dozens of radios beaming concentric rings around the Sierra de Segovia where our hero was fighting. After seven years of fruitless pursuit they had to grant him a truce on his own terms. Augusto César Sandino, the Nicaraguan patriot, was assassinated a short time after leaving the Segovia highlands. ${ }^{\prime 121}$ It is curious that Bayo makes such an inspirational statement about a person whom he never met, but that he never made the slightest trace of an attempt to mention any of his experiences in Spanish Morocco, where he had fought for eleven years. ${ }^{122}$

It is alleged that Bayo got to know about Sandino's tactics through former Sandino followers whom he trained in Costa Rica to overthrow the Somoza dictatorship in Nicaragua in 1948. ${ }^{123}$ Dosal, for instance, states that Bayo got firsthand information about Sandino's campaigns from some of the Nicaraguan veterans who had joined him for the Cuban revolution. ${ }^{124}$ However, when training the rebels for the Cuban revolution, Bayo was already a 64-year-old war veteran. He had significant war experience, with the Rif war being the only guerrilla war he fought against. The claim that Bayo learned guerilla warfare from Sandino can be easily disproved with the following three reasons:

Firstly, Sandino's revolt started as soon as the Rif war ended in 1927. Nevertheless, guerrilla tactics long practiced by the Rifis were picked up by Sandino only gradually after failed conventional assaults. Sandino experienced his first failure in July 1927 when he attacked - with about eight hundred peasants led by sixty officers-American marines and its native arm the Guardia, who had occupied buildings in Ocotal. ${ }^{125}$ The marines instantly called for air support. Five De Havilland planes subsequently destroyed almost half of Sandino's army. Dosal remarks that this incident taught Sandino that "recent developments in military technology and tactics, namely the use of airplanes, machine guns, and dive-bombing, made it impossible for roving bands of cavalry to mass in open fields or deserts."126"

Secondly, the American administration suppressed Sandino's rebellion in Nicaragua predominantly through air attacks, and these were reduced in favour of ground operations only towards the end of the five and a half years during which operations lasted. Accordingly, Sandino's tactics related primarily to fighting off their powerful aerial persecutors in the air equipped with the latest machine guns and bombs. His tactics included, for instance, methods on how to become invisible and how to avoid suspicion from air. As the pilots were dropping bombs upon observing any sudden or panicky reactions, Sandino instructed the rebels, for instance, not to use horses, as these were difficult to lead in the dense forest and hence attracted the attention of the patrolling pilots from the sky more readily. ${ }^{127}$ Eyewitnesses of the time report that upon noticing an airplane, some rebels would remain motionless while others would start making music in order to avert suspicion. ${ }^{128}$ In El Chipote, Sandino had managed to deceive pilots by putting up scarecrows, thereby inflicting heavy losses on the marines. ${ }^{129}$ The rebels were also employing tactics which appealed to the conscience of the airmen. The airmen were warned, especially shortly before diving to an attack, not to be tricked if their target column transfigured itself all of a sudden into women holding a "highly tanned baby in each arm." 130 The marines also recorded incidents where women Q3 were used as human shields against air attacks. ${ }^{131}$ Sandino himself adhered the relative success of his struggle to deception of the foreign forces. Overall, however, his success was due to intelligence support he used to receive from the populace and his soldiers: "Our Army's success," Sandino himself said, "is the result of our espionage service. The enemy doesn't carry out a maneuver that we don't know about at once."132 Abd-el-Krim's resistance, however, amazed the world not solely for its intelligence services. 
The admiration was related to the various tactical methods applied and their fighting performance, as stated above.

Apart from tactical disparities, Bayo's 150 Questions for a Guerilla contains recommendations which do not necessarily conform with Sandino's practices. For instance, Bayo clearly advises to avoid ineffectual outfit (question 44). Abd-elKrim's regular troops (about 10,000 men) consisting of infantry and artillery wore military uniforms. ${ }^{133}$ The traditional tribal dress was retained in most cases, but the soldiers wore different colours of turbans to denote their rank. ${ }^{134}$

Thirdly, there is another important point which weakens the credibility of the claim that Bayo was inspired by the tactics of Sandino. Given the extreme imbalance of power between the rebel forces (aka troops of grass) ${ }^{135}$ and the aircrews who were exploring modern warfare with airplanes by dropping bomb after bomb and expending thousands of rounds of machine-gun ammunition, Sandino not only attracted the sympathies of his own people but also of the American public. During the raids, innocent people including women and children were killed, houses and livestock was destroyed. This increased Sandino's popularity and the number of his followers. The mass atrocities inflicted by the marines were never forgotten by the Nicaraguans. Memories of collective victimization became an inherent feature of the Nicaraguan society and continued to be felt long after the end of the war. Since the end of the 20s, the atrocities and Sandino's untiring dedication to challenging the American airplanes never ceased to be expressed in stories and poems, and were even used for the purpose of political mobilization throughout Latin America. In the literary tradition Sandino is mystified and presented as a crafty rebel leader who always manages to fool the technologically superior opponent by applying certain tricks. Psychologically, such expressions can be seen as a result of wounded pride. Thus, it is reasonable to assume that Bayo had mentioned Sandino in his 150 Questions for a Guerilla simply because it was likely to appeal more to the prospective Latin American guerilla soldier than any other rebel chieftain. Perhaps the following statement by Bockman can be extended to apply to inspirational measures adopted by Bayo as well: "Bayo, and especially Guevara, became quite adept at altering established guerrilla tactical theory to suit Cuba's social conditions and terrain. They recognized the need to recruit young people who could endure the hardships of guerrilla fighting." 136 Bayo's reference to Sandino may well have been also due to gratitude - after all, it was a group of Nicaraguan veterans who had promoted him to the rank of "general" in 1948.

\section{Conclusion}

It is known for certain that Che applied at least one guerilla tactic of the Rifis: According to Castro, Che learned from his guerilla trainer Alberto Bayo the Rifi method of breaking through enemy lines when encircled. Che even earned a lot of praise, such as from the American Major Larry Bockman in 1984, for his successful application of this tactic to help out Castro and his troops who were entrapped by the Batista forces in July 1958. Bayo does mention this particular method in his famous 150 Questions for a Guerilla, but he does not give any reference to its origin. At some other point in his manual, he briefly expresses praise for Sandino. Nevertheless, some other methods mentioned in his work - such as digging a tunnel up to the target building to destroy it with explosives, composition of the optimal size of guerilla units and their military dress code-bear a striking resemblance to the 
Rifi tactics, suggesting that Bayo may have had copied at least a few guerilla methods from the Rifis. The guerilla training sessions Alberto Bayo was giving to the Cuban rebels in Sierra Maestra surely incorporated other methods than just imparting the tactics of breaking through a siege. Hence, this work has also looked at the guerilla principles of the Rifis, which are claimed to have been emulated by other resistance groups throughout the world, and compared these to the resistance led by Che. The comparison additionally confirmed the previous findings, notably that some of the Rifi guerilla war methods, such as their siege war techniques and their method of attacking armored cars, equally found application during Che's guerilla operations. What is striking, however, is that the age-old tactic ambush technique, to which Che is claimed to have made an original contribution through his idea of systematically attacking the vanguard with the aim of stirring up anxiety among the following units to be in advance positions, was common practice among the Rifi warriors decades earlier.

Military knowledge transmission across guerrilla movements through official military staff, as carried out by Alberto Bayo, is not a rare phenomenon. Collaborations and desertions have always plagued official armies everywhere around the world. Alberto Bayo did not desert, but his decision to train guerilla fightersthough years later and elsewhere - after leaving his work in the Spanish army gives reason to classify him as "deserter." Despite their tactical innovations and fighting expertise, the Rifis, too, were heavily reliant upon know-how from outside the borders of their own country, particularly with regard to technology-intensive weapons systems. Indeed, among the not too few deserters, Abd-el-Krim was especially keen on those who were able to impart their technical skills on the usage of the arms confiscated during the battle of Annual and Monte Arruit. ${ }^{137}$ Bayo's profession was related to operating the most advanced technological war device of the time, namely planes, with immense destructive potential, which had just begun to be used during wars. His intensive occupation with guerilla war methods clearly indicate his insight for the viability of such operations against technologically far better equipped opponents. The relative success of the Rif rebellion as well as those mentioned in this article, additionally confirm that tactical skills, which are brought about by environmental factors such as by challenging natural circumstances and/or tradition, are much more decisive for the success of armed movements than technological competence in the use of weapons.

In today's world, knowledge transfer along similar lines can be expected to take place also among terrorist groups. Given the advantages of modern means of communication, expertise on guerilla tactics, be it through online sources or through contacts via social media, can be acquired easily. Furthermore, despite strictest measures, transnational transfer of classified information on military know-how and skills cannot be prevented entirely and there is always the risk of leakages through employee fluctuations between companies and/or through attacks by hackers. Nevertheless, knowledge transfers of this nature may not necessarily bring either the war expertise or the military arsenal of any rebellion initiative on an equal footing with the technologically and militarily advanced states, and rebellions can still be suppressed relatively easily.

What seems to be much more difficult to control is people, who find role models in "inspirational personalities and heroes" such as Che Guevara, Abd-el-Krim, or Sandino, just to mention a few, in the face of injustice. Certainly, the Internet has also greatly facilitated the acquisition of knowledge about these and many other 
revolutionaries across the world by much wider audiences. Along with these developments, there is an ever-growing trend among historians to write biographies of revolutionaries. Life stories are taken up decades, if not centuries, later, as can be seen from the studies on Abd-el-Krim's struggle mentioned above. Similarly, there is an insatiable interest in any aspect of Che's life. There seems to be also a growing tendency to declare leaders of long passed revolutions as national heroes decades later as, for instance, in the case of the Indonesian female guerilla leader Cut Nyak Dhien (1848-1908) by the Indonesian government, as late as about sixty years after, in 1964. Dhien had initiated a 25-year lasting rebellion against the Dutch colonial army in Indonesia in the period between 1876 and 1901. These trends are also growing in importance among filmmakers. A few examples are worth mentioning: The rebellion of the Libyan guerilla leader Omar Mukhtar (1858-1931) against the Italian occupants of his country was filmed under the title Lion of the Desert (1981) and, to date, it is considered as one of the most popular productions especially in the Muslim world. Similarly, the life story of Cut Nyak Dhien, filmed under the title Tjoet Nja' Dhien in 1988, won the Cannes Film Festival's Best International Film award in 1989. Che's life, filmed in 2008, was also met with great interest all over the world. Further research is needed here, in order to gain more profound understanding of the impact of such productions, biographies of guerilla leaders, and even biographical novels with factual information on their lives.

\section{Notes}

1. Rudibert Kunz and Rolf-Dieter Müller, Giftgas gegen Abd el Krim. Deutschland, Spanien und der Gaskrieg in Spanisch-Marokko 1922-1927 (Freiburg im Breisgau: Rombach Freiburg Verlag, 1990), 17.

2. C. R. Pennell, A Country with a Government and a Flag: The Rif War in Morocco, 1921-1926 (Cambridgeshire: MENAS Press, 1986), 237.

3. Abd-el-Krim, Memoiren, Mein Krieg gegen Spanien und Frankreich (Dresden: Carl Reissner Verlag, 1927), 10-11.

4. John Bode, Abd El Krim's Freiheitskampf gegen Franzosen und Spanier (Charlottenburg: Verlag Offene Worte, 1926), 18.

5. Abd-el-Krim, Memoiren (see note 3 above), 41, 55.

6. Ibid., 39.

7. Ibid., 10 .

8. Ibid., 41.

9. Shannon E. Fleming, Primo de Rivera and Abd-e-Krim: The Struggle in Spanish Morocco, 1923-1927 (New York: Garland Publishing, 1991), 60.

10. Fleming, Primo de Rivera and Abd-e-Krim (see note 9 above), 60-61.

11. Ibid., 61.

12. See the article by Abd-el-Krim in the Telegrama del Rif (October 1910).

13. Bernd Terhorst, Feuer am Rif. Zwei Jahre unter Rifkabylen (Berlin: Neufeld und Henius, 1925), 154.

14. Alfred Zaeper, Unter der Glutsonne Marokkos gegen Ab del Krim (Leipzig: Verlag

Wahrheit, Ferdinand Spohr, 1932), 24. This incident took place at the end of May 1925.

15. Germain Ayache, Les origines de la guerre du Rif (Rabat/Paris: 1981), 182.

16. Ibid., 217.

17. Pennell, A Country with a Government and a Flag (see note 2 above), 65.

18. Abd-el-Krim, Memoiren (see note 3 above), 57.

19. David M. Hart, The Aith Waryaghar of the Moroccan Rif: An Ethnography and

History (Tucson: University of Arizona Press, 1976), 373.

20. Pennell, A Country with a Government and a Flag (see note 2 above), 74.

21. Ibid., 81 .

22. Hart, The Aith Waryaghar of the Moroccan Rif (see note 19 above), 374. 
23. In particular concerning numbers, there are great disparities in the literature; See Fouzia El-Asrouti, Der Rif-Krieg 1921-1926: Eine kritische Untersuchung des gesellschaftlichen Transformationsprozesses unter Muhammad ibn Abd al-Karim al Hattabi (Berlin: Klaus-Schwarz-Verlag, 2007), 61, 92, 95. The total number of the Rifi army (regular and local) is estimated to have been around 80,000; see David S. Woolman, Rebels in the Rif: Abd-elKrim and the Rif Rebellion (Stanford: Stanford University Press, 1968), 149.

24. See El-Asrouti, Der Rif-Krieg 1921-1926 (see note 23 above), 61; Sasse states a figure of 8,000. Dirk Sasse, Franzosen, Briten und Deutsche im Rifkrieg 1921-1926: Spekulanten und Sympathisanten, Deserteure und Hasardeure im Dienste Abdelkrims (München: Oldenbourg Wissenschaftsverlag, 2006), 40.

25. Hart, The Aith Waryaghar of the Moroccan Rif (see note 19 above), 374.

26. Pennell, A Country with a Government and a Flag (see note 2 above), 168.

27. There are significant disparities in the existing literature concerning the death toll on both sides. This number is based upon the analysis by Pennell, A Country with a Government and a Flag (see note 2 above), 176.

28. Kunz and Müller, Giftgas gegen Abd el Krim (see note 1 above).

29. This was done under the guidance of Marshal Pétain. See also: Two Papers on France Concerning the French Judicial System under Vichy and French Acquisition of Morocco (The National Archives, UK, April 17, 1943), TNA number: FO 371/36016-0022. Section/ Department: French.

30. Sasse, Franzosen, Briten und Deutsche im Rifkrieg 1921-1926 (see note 24 above), 51. Pröbster (p. 154) makes the following statement concerning the number of troops on each side: "On the 9th July 1925 the French decided to increase the number of their troops to 150,000. The Spanish army consisted of about 100,000 Soldiers. In contrast, the number of the Rifis were at most 40,000-50,000. The aim of the Franco-Spanish army consisting of a quarter million men was to destroy the Rif republic founded by Abd-el-Krim." With regard to the number of Rifi troops Pröbster (p. 158) adds: "Marshal Pétain estimates this figure to be between 30,000 and 40,000." Edgar Pröbster, "Die Befriedung der Berbern und der Rifkrieg," Preußische Jahrbücher 202 (1925): 147-164.

31. Anthony Clayton, France, Soldiers and Africa (London: Brassey's, 1988), 110 cited in Sasse (see note 24 above), 56.

32. This might be due to the swiftness of the Rifis: Abd el Krim attempted to escape on December 23, 1915, too, when he was imprisoned by the Spanish on September 6, 1915 but failed as he broke his leg. He was released in return for his father's support for the landing of the Spanish at the bay of Alhucemas; Abd el Krim, Memoiren (see note 3 above), 46.

33. Martin Windrow, Our Friends beneath the Sands: The Foreign Legion in France's Colonial Conquests: 1870-1935 (London: Weidenfeld \& Nicolson, 2010), 482.

34. Ibid., 525.

35. Ibid., 511.

36. Ibid., 523-524.

37. Woolman, Rebels in the Rif (see note 23 above), 108; Windrow, Our Friends beneath the Sands (see note 33 above), 555.

38. Sasse, Franzosen, Briten und Deutsche im Rifkrieg 1921-1926 (see note 24 above), 96.

39. Henk Sneevliet, The Class Struggle Element in the Liberation Struggle of the Indonesian People, First Published: Klassenstrijd (1926), 17. Original Language Source: Teksten van Revolutionaire socialisten 1911-1942. Uitgave herdenkingscomité April 13October 16, 1942, http://www.marxists.org/archive/sneevliet/1926/class-liberation.htm.

40. Richard Seymour, The Liberal Defence of Murder (USA: Verso, 2008), 62.

41. Sneevliet, The Class Struggle Element in the Liberation Struggle of the Indonesian People (see note 39 above).

42. Fidel Castro and Ignacio Ramonet, My Life: A Spoken Autobiography (USA: Scribner, 2008), 162, 168. Sebastian Balfour, Deadly Embrace: Morocco and the Road to the Spanish Civil War (USA: Oxford University Press, 2002).

43. Communication took place via e-mail on May 6, 2009. See also Paul J. Dosal, Comandante Che: Guerrilla Soldier, Commander, and Strategist, 1956-1967 (USA: The Pennsylvania State University Press, 2010), 49.

44. "Le Che chez nous" by Hamdani in Telquel, No. 240, September 23-29, 2006. 
45. Zinovi Pechkoff, Bugle Sounds: Life in The Foreign Legion (New York and London: Appleton, 1926), 141, 211, 228; Woolman, Rebels in the Rif (see note 23 above), 192.

46. Woolman, Rebels in the Rif (see note 23 above), 184.

47. "Le Che chez nous" by Hamdani in Telquel, No. 240, September 23-29, 2006.

48. Woolman, Rebels in the Rif (see note 23 above), 156.

49. Abd el Krim, Memoiren (see note 3 above), 67.

50. Windrow, Our Friends beneath the Sands (see note 33 above), 532.

51. Ibid., 533.

52. Kunz and Müller, Giftgas gegen Abd el Krim (see note 1 above), 58.

53. Ibid., 58.

54. Woolman, Rebels in the Rif (see note 23 above), 105.

55. Windrow, Our Friends beneath the Sands (see note 33 above), 498. 1985).

56. John Scurr, The Spanish Foreign Legion (London: Osprey Men-at-Arms Publishing, 985

57. Windrow, Our Friends beneath the Sands (see note 33 above), 471.

58. Sneevliet, The Class Struggle Element in the Liberation Struggle of the Indonesian People (see note 39 above).

59. Ernesto Che Guevara, Guerrilla Warfare (Lincoln and London: University of 990 Nebraska Press, 1985), 93.

60. In a personal conversation with Richard Baber-an expert in the field of War Studies and the editor of The SOTCW World War I Compendium —on May 19, 2014.

61. Argosy Weekly, Vol. 257, no. 1 (July 13, 1935).

62. Sasse, Franzosen, Briten und Deutsche im Rifkrieg 1921-1926 (see note 24 above), 995 $136,153$.

63. Ibid., 135.

64. Percival Christopher Wren, Stories of the Foreign Legion (First edition in one volume) (1947), http://gutenberg.net.au/ebooks07/0700341h.html\#c301. 136.

65. Sasse, Franzosen, Briten und Deutsche im Rifkrieg 1921-1926 (see note 24 above),

66. The title of the 1977 version is The Last Remake of Beau Geste and is a comedy.

67. The 1943 version does not relate to the Rif war but to World War II.

68. William A. Everett, Sigmund Romberg (New Haven, CT: Yale University Press, 2007), 262.

69. Ibid., 158.

70. San Francisco Chronicle, Oct. 24, 1926.

71. Castro and Ramonet, My Life: A Spoken Autobiography (see note 42 above), 496.

72. María Teresa Suero Roca, "Alberto Bayo Giroud," in Tiempos de Historia (May 1979): 18, http://gredos.usal.es/jspui/bitstream/10366/24016/3/THV N54 P18-29.pdf.

73. Dosal, Comandante Che (see note 43 above), 49.

74. María Elena Vallés, "Bayo, el hombre que quiso ganar la Guerra en Mallorca," in Diario de Mallorca, October 24, 2010.

75. Richard L. Harris, Che Guevara: A Biography (California: Greenwood, ABC-CLIO, 2010), 61 .

76. Thomas Hugh, Castros Cuba (Berlin: Siedler Verlag, 1984), 74-78.

77. Dosal, Comandante Che (see note 43 above), 49.

78. Werner Abel and Peter Fisch, Bayos Warnung wurde blutige Realität.Vor 75 Jahren putschen Spaniens Generale - Mallorca im Krieg, (Teil 2), July 23, 2011, http:// www.neues-deutschland.de/artikel/202717.bayos-warnung-wurde-blutige-realitaet.html.

79. Joseph Hansen, "The Truth about Cuba," in Militant (Pioneer Publishers, 1960), Q11 Q10 http://www.walterlippmann.com/hansen-truth-about-cuba.html

80. Harris, Che Guevara: A Biography (see note 75 above), 72-73.

81. See the picture in Rupert Furneaux, Abdel Krim, Emir of the Rif (London: Secker \& Warburg, 1967), 96.

82. Ibid., $65,96$.

83. Sasse, Franzosen, Briten und Deutsche im Rifkrieg 1921-1926 (see note 24 above), 96.

84. See Castro and Ramonet, My Life: A Spoken Autobiography (see note 42 above), 174. See also Enrique Atiénzar Rivero, "El gladiador," in Adelante, July 11, 2013. 
85. Balfour, Deadly Embrace (see note 42 above) 2002 cited in "Timeline for the Third 1030 Rif War 1920-25" by Steven Thomas, http://balagan.info/timeline-for-the-third-rif-war1920-25.

86. Woolman, Rebels in the Rif (see note 23 above), 90, 104, 136. Robert L. Scheina, Latin America's Wars, The Age of the Professional Soldier, 1900-2001, Vol. 2 (Virginia: Potomac Books, 2003), 220.

87. Windrow, Our Friends beneath the Sands (see note 33 above), 498.

88. Ibid., (see note 33 above), 541.

89. Harris, Che Guevara: A Biography (see note 75 above), 81; Larry Bockman, The Spirit of Moncada: Fidel Castro's Rise To Power, 1953-1959 (Marine Corps Command and Staff College, 1984), http://www.globalsecurity.org/military/library/report/1984/BLJ.htm 90. Harris, Che Guevara: A Biography (see note 75 above), 112.

91. Ernesto Che Guevara, Episodes of the Revolutionary War, 1956-1958, Mary-Alice Waters, ed. (New York: Pathfinder Press, 1996), 100, cited in Harris, Che Guevara: A Biography (see note 75 above), 79.

92. Guevara, Episodes of the Revolutionary War, 1956-1958 (see note 91 above), 211, cited in Dosal, Comandante Che (see note 43 above), 99.

93. Dosal, Comandante Che (see note 43 above), 309.

94. Windrow, Our Friends beneath the Sands (see note 33 above), 470.

95. Ibid., 543.

96. Ibid., 470.

97. Ibid., 470 .

98. Ibid., 483.

99. Ibid., 491.

100. Ibid., 491.

101. Ibid., 491.

102. Ibid., 484.

103. Ibid., 464.

104. Sasse, Franzosen, Briten und Deutsche im Rifkrieg 1921-1926 (see note 24 above), 100.

105. Ibid., 105.

106. Woolman, Rebels in the Rif (see note 23 above), 103.

107. Scheina, Latin America's Wars (see note 86 above), 58, 219, 220, 234; Dosal, Comandante Che (see note 43 above), 77, 235.

108. Dosal, Comandante Che (see note 43 above), 58, 234.

109. Scheina, Latin America's Wars (see note 86 above), 220.

110. Harris, Che Guevara: A Biography (see note 75 above), 85 .

111. Dosal, Comandante Che (see note 43 above), 75-77.

112. Ibid., 88-90.

113. Ibid., 235.

114. Harris, Che Guevara: A Biography (see note 75 above), 80.

115. Ibid., 86-87.

116. Ibid., 111.

117. Windrow, Our Friends beneath the Sands (see note 33 above), 470.

118. Ibid., 498.

119. Woolman, Rebels in the Rif (see note 23 above), 184.

1050

120. Donald C. Hodges, Intellectual Foundations of the Nicaraguan Revolution (Austin: University of Texas Press, 1986), 167.

121. Alberto Bayo, 150 Questions for a Guerilla (Boulder, CO: Panther Publications, 1962), 31.

122. Dosal, Comandante Che (see note 43 above), 49; Bockman, The Spirit of Moncada (see note 89 above), 20

123. Hodges, Intellectual Foundations of the Nicaraguan Revolution (see note 120 above), 167.

124. Dosal, Comandante Che (see note 43 above), 51.

125. Ibid., 51.

126. Ibid., 52. 
127. Michael J. Schroeder, "Social Memory and Tactical Doctrine: The Air War in Nicaragua during the Sandino Rebellion, 1927-1932," The International History Review, 24, no. 3 (September 2007): 539-540, http://www.sandinorebellion.com/mjs/MJS-AirWarIn Nicaragua-IHR-Sept07.pdf.

128. Ibid., 540 .

129. Ibid., 524.

130. Ibid., 538,540 .

131. Ibid., 543.

132. Augusto C. Sandino, Sandino: The Testimony of a Nicaraguan Patriot 1921-34, compiled and edited by Sergio Ramírez (Princeton, NJ: Princeton University Press, 1990), 276, cited in: Scheina, Latin America's Wars (see note 86 above), 72.

133. Bode, Abd El Krim's Freiheitskampf gegen Franzosen und Spanier (see note 4 above), 22; Furneaux, Abdel Krim, Emir of the Rif (see note 81 above), 117.

134. Windrow, Our Friends beneath the Sands (see note 33 above), 497.

135. In a poem by Ernesto Cardenal, "Zero hour" (1956).

136. Bockman, The Spirit of Moncada (see note 89 above), 113.

137. The names of the most prominent trainers are mentioned in Sasse, Franzosen, Briten und Deutsche im Rifkrieg 1921-1926 (see note 24 above), 100-101. 